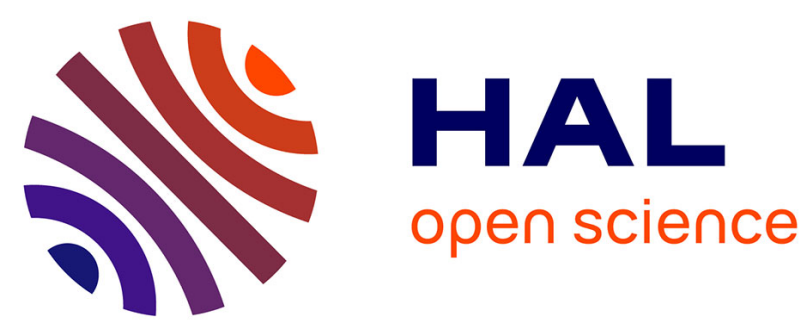

\title{
Recovery of severely deformed ferrite studied by in situ high energy X-ray diffraction
}

Clélia Couchet, Sébastien y P Allain, Guillaume Geandier, Julien Teixeira, Steve Gaudez, Juan Macchi, Mathias Lamari, Frédéric Bonnet

\section{To cite this version:}

Clélia Couchet, Sébastien y P Allain, Guillaume Geandier, Julien Teixeira, Steve Gaudez, et al.. Recovery of severely deformed ferrite studied by in situ high energy X-ray diffraction. Materials Characterization, 2021, 179, pp.111378. 10.1016/j.matchar.2021.111378 . hal-03325592

\section{HAL Id: hal-03325592 \\ https://hal.science/hal-03325592}

Submitted on 25 Aug 2021

HAL is a multi-disciplinary open access archive for the deposit and dissemination of scientific research documents, whether they are published or not. The documents may come from teaching and research institutions in France or abroad, or from public or private research centers.
L'archive ouverte pluridisciplinaire HAL, est destinée au dépôt et à la diffusion de documents scientifiques de niveau recherche, publiés ou non, émanant des établissements d'enseignement et de recherche français ou étrangers, des laboratoires publics ou privés. 


\title{
Recovery of severely deformed ferrite studied by in situ high energy $\mathrm{X}$-Ray diffraction
}

\author{
Clélia Couchet ${ }^{1,2}$, Sébastien Y.P. Allain ${ }^{1}$, Guillaume Geandier ${ }^{1}$, Julien Teixeira ${ }^{1}$, Steve Gaudez ${ }^{1}$, Juan \\ Macchi $^{1}$, Mathias Lamari ${ }^{1,2}$ and Frédéric Bonnet ${ }^{2}$ \\ ${ }^{1}$ Université de Lorraine, CNRS, IJL, F-54000 Nancy, France \\ ${ }^{2}$ ArcelorMittal Maizières Research SA, 57280 Maizières les Metz, France
}

\section{Highlights :}

- Recovery of severely deformed ferrite was followed in situ by High Energy X Ray Diffraction during heating and isothermal holding experiments.

- Dislocation densities during annealing were determined by a modified Williamson Hall method.

- A saturation in recovery has been observed in all studied conditions whatever the holding temperature.

- The beginning of recrystallization is detected by a large density drop at $650{ }^{\circ} \mathrm{C}$.

\begin{abstract}
:
Recovery of severely deformed ferrite was followed in situ by High Energy X Ray Diffraction during heating and isothermal holding experiments. Dislocation densities during annealing were determined by a modified Williamson Hall method. The deduced recovery kinetics was compared to post-mortem hardness measurements. A temperature dependent saturation of recovery was highlighted during holding. Dislocation density drop and saturation behavior cannot be reproduced simultaneously by the classical physically based models.
\end{abstract}

Keywords : Recovery, ferrite, dislocation density, modified Williamson-Hall, HEXRD

\section{Graphical abstract :}

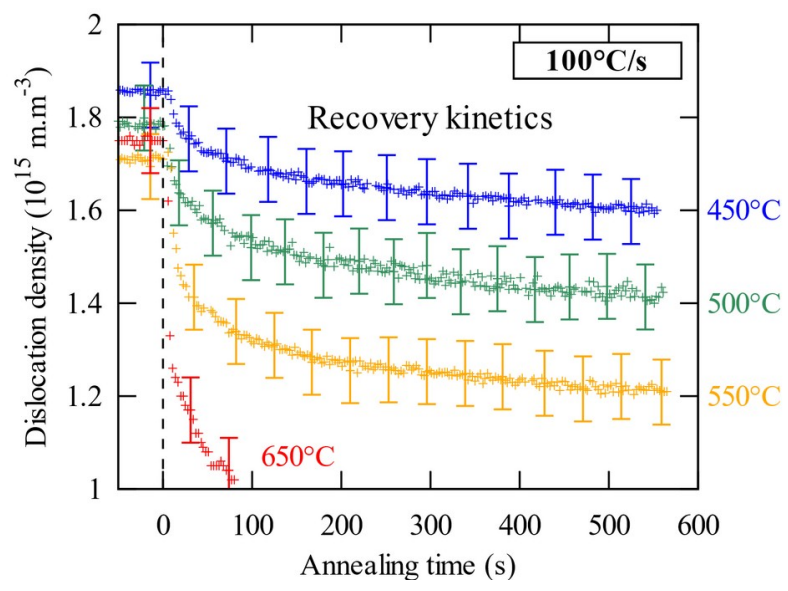




\section{Introduction}

Dual-Phase (DP) steels are mostly produced by annealing of cold rolled ferrite-pearlite microstructure in the intercritical range [1]-[5]. Recovery is one of the numerous metallurgical mechanisms occurring in ferritic matrix during the heating [6], [7] and consists of the decrease in the density of deformation induced crystalline defects [6]-[10]. During this stage, the reduction in dislocation density and the reorganization and growth of sub-grains lead to a decrease in their associated elastic energy. These changes in the microstructure of deformed ferrite during the heating stage of the annealing of cold-rolled steels affects in turn the recrystallisation of ferrite. As recrystallization and austenite phase transformation can happen simultaneously at higher temperatures, their interactions affect the morphogenesis of ferrite-austenite microstructure. The resulting size and morphology of the phases govern the final tensile and damage properties of the steels [11]-[13]. Thus, recovery at low temperature is a key and current concern for steelmakers. As a consequence, experimental characterization and modeling of recovery is of great interest [4], [14]-[19].

In the present work, the recovery was studied in a cold rolled ultra-low carbon ferritic steel (0.0004 wt $\% \mathrm{C}$ ) by determining the dislocation density during annealing at temperatures between $450{ }^{\circ} \mathrm{C}$ and $650{ }^{\circ} \mathrm{C}$ after slow $\left(3^{\circ} \mathrm{C} / \mathrm{s}\right)$ or fast $\left(100^{\circ} \mathrm{C} / \mathrm{s}\right)$ heating. This steel serves as a model alloy to mimic the behavior of the sole ferritic matrix of conventional ferrite-pearlite microstructures for DP production.

\section{Material and methods}

Chemical composition of the investigated ferritic steel is given in Table 1. The cold-rolled steel sheets have been provided by ArcelorMittal Maizières Research. The steel ingots were elaborated in a vacuum induction melting furnace, and further hot-rolled. The thickness of sheets after this operation was $3.3 \mathrm{~mm}$. The sheets were then cold rolled to $1.7 \mathrm{~mm}$ in a laboratory mill. The final cold-rolling ratio is about $120 \%$ which is representative of the deformation of the ferritic matrix in the ferrite-pearlite steel cold rolled at $60 \%$ [20]. Parallelepipedal samples $10 \times 5 \times 1.2 \mathrm{~mm}^{3}$ were machined from as cold-rolled steel sheets.

Table 1: Chemical composition of the studied ferritic steel, wt $\%$

\begin{tabular}{cccccccc}
$\mathrm{C}$ & $\mathrm{Si}$ & $\mathrm{Mn}$ & $\mathrm{P}$ & $\mathrm{S}$ & $\mathrm{Cr}$ & $\mathrm{Al}$ & $\mathrm{Cu}$ \\
\hline \hline 0.0004 & 0.245 & 1.860 & 0.002 & 0.001 & 0.206 & 0.039 & $<0.002$
\end{tabular}

Recovery has been investigated thanks to in situ High Energy X-Ray Diffraction (HEXRD) experiments. These experiments in transmission conditions were carried out on P07 beamline in PETRA III at DESY (Hamburg) with a monochromatic beam (100 keV). Debye-Scherrer (DS) diffraction rings have been acquired at about $0.33 \mathrm{~Hz}$ with a 2D Perkin-Elmer detector. Annealing simulations have been conducted in a Bahr dilatometer and consisted in isothermal holding at $450{ }^{\circ} \mathrm{C}, 500{ }^{\circ} \mathrm{C}, 550{ }^{\circ} \mathrm{C}$ and $650{ }^{\circ} \mathrm{C}$ after slow and fast heating $\left(3^{\circ} \mathrm{C} / \mathrm{s}\right.$ and $100{ }^{\circ} \mathrm{C} / \mathrm{s}$ respectively) to force recovery, before heating again up to $800{ }^{\circ} \mathrm{C}$ to study the resulting phase transformation kinetics and morphogenesis (not detailed in the present paper). Eight experiments have been conducted in total.

1D diffraction patterns are obtained by complete azimuthal integration of DS rings using PyFAI [21] for each 2D pattern (about 230 patterns were analyzed for each experiment). Only diffraction peaks of ferrite are observed (no carbides, no retained austenite). The first five diffraction peaks, corresponding to diffraction planes $\{110\},\{200\},\{211\},\{220\}$ and $\{310\}$, are individually modeled thanks to Pearson VII functions giving the position $2 \theta_{0}\left(^{\circ}\right)$ and the Half Width Half Maximum $\mathrm{HWHM}_{\bmod }\left(^{\circ}\right)$ of each peak. Local background around $2 \theta_{0} \pm 0.5^{\circ}$ is considered linear. The Trust Region Reflective [22] method is used to fit this model to experimental data. The contribution of thermal agitation to the HWHM has been estimated using FullProf with and without the overall temperature factor (BOV). This contribution leads to an 
overevaluation of the HWHM of only about $2 \%$ (relative error) and will be neglected in our further developpements. HWHM broadening due to instrumental set up was accounted and the corrected $\mathrm{HWHM}_{\text {corr }}$ is calculated as follows:

$$
H W H M_{\text {corr }}\left(2 \theta_{0}\right)=\sqrt{H W H M_{\text {mod }}\left(2 \theta_{0}\right)^{2}-H W H M_{\text {instr }}\left(2 \theta_{0}\right)^{2}}
$$

With $2 \theta_{0}$ the position of the diffraction peak and $\operatorname{HWHM}_{\text {instr }}\left(2 \theta_{0}\right)=\mathrm{A}\left(2 \theta_{0}\right)^{2}$ the instrumental broadening calibrated on $\mathrm{LaB}_{6}$ powder. A is estimated at $1.62 \times 10^{-5}\left({ }^{\circ}\right)^{-1}$.

From these $\mathrm{HWHM}_{\text {corr }}$ values, dislocation density is determined thanks to the modified Williamson-Hall method (mWH) elaborated by Ungar et al. [23]-[25]. In this approach, the magnitude of the diffraction vector $K=\frac{2 \sin \left(\theta_{0}\right)}{\lambda}$ is related to its variation $\Delta K=\frac{2 \cos \left(\theta_{0}\right)}{\lambda} H W H M_{\text {corr }}\left(2 \theta_{0}\right)$ [24], [26] as follows:

$$
\Delta K=\frac{k}{D}+\frac{\pi}{2} R_{e}^{2} b^{2} \rho^{\frac{3}{2}}(K \sqrt{\bar{C}})^{2}
$$

With $\rho$ the dislocation density $\left(\mathrm{m} \cdot \mathrm{m}^{-3}\right)$, $\mathrm{D}$ the crystallite size $(\mathrm{m}), \mathrm{k}$ a constant taken equal to $0.94, \mathrm{R}_{\mathrm{e}}$ the cut-off radius (m), $\bar{C}$ the average contrast factor and $\mathrm{b}=2.5 \times 10^{-10} \mathrm{~m}$ the magnitude of the Burgers vector $(\mathrm{m})$.

The cut-off radius $\mathrm{R}_{\mathrm{e}}$, defining the area of influence of a dislocation, is the most difficult parameter to estimate. By coupling mWH and Warren-Averbach methods [26]-[28], values ranging between 10 and $40 \mathrm{~nm}$ are reported in literature. In our work, $R_{e}$ is set at $8.5 \mathrm{~nm}$ to obtain an initial dislocation density $\rho_{0}=1.9 \times 10^{15} \mathrm{~m} . \mathrm{m}^{-3}$ in as cold rolled state. This value is predicted by the micromechanical model detailed in [20]. In that sense, the values of dislocation densities shown below are not absolute as the determination required parameters which cannot be assessed independently.

The average contrast factor $\bar{C}$ of each diffracting crystalline plane family depends on the Miller's indexes (hkl) of the plane and the mean characters of dislocations (assuming they are either screw or edge). If $\mathrm{S}$ is the relative proportion of screw dislocations, the average contrast factor $\bar{C}$ is calculated as follows [27], [28]:

$$
\bar{C}=\left(\overline{C_{h 00}^{E}}(1-S)+\overline{C_{h 00}^{S}} S\right)\left[1-\left(q^{E}(1-S)+q^{S} S\right) H^{2}\right]
$$

With $H^{2}=\frac{h^{2} k^{2}+h^{2} l^{2}+k^{2} l^{2}}{h^{2}+k^{2}+l^{2}}, \overline{C_{h 00}^{E}}$ and $\overline{C_{h 00}^{S}}$ denoting the average contrast factor in the crystal plane family $\{\mathrm{h} 00\}$ for edge and screw dislocations respectively and $q^{E}$ and $q^{S}$ are constants. These parameters are computed thanks to ANIZC software [29]. They depend on the anisotropic elastic behavior of the ferritic lattice and thus on temperature (the reader can refer to appendix A. for more details). Elastic constants $\mathrm{C}_{11}, \mathrm{C}_{12}$ et $\mathrm{C}_{44}$ are computed for the studied steel composition and temperatures ranging from $27^{\circ} \mathrm{C}(300 \mathrm{~K})$ to $650^{\circ} \mathrm{C}$ using the empirical Ghosh and Olson's model [30] (the reader can refer to appendix B. for more details).

For a given 2D pattern, each diffracting plane family determines a couple $\mathrm{K}^{2} \mathrm{C}-\Delta \mathrm{K}$ knowing its diffraction angle $\theta_{0}$ and $H W H M_{\text {corr }}$. A linear regression conducted on these values leads to the dislocation density $\rho$ and the crystallite size $\mathrm{D}$ by determining the slope and the intercept at origin respectively.

In parallel to these in situ experiments, conventional hardness measurements (HV 0.5) were carried out on samples in the cold rolled state and after interrupted treatments. The samples were heated at 
$3{ }^{\circ} \mathrm{C} / \mathrm{s}$ or $100{ }^{\circ} \mathrm{C} / \mathrm{s}$ up to $550{ }^{\circ} \mathrm{C}$ and gas (He) quenched after various holding times $(0 \mathrm{~s}, 50 \mathrm{~s}, 100 \mathrm{~s}$, $200 \mathrm{~s}$ and $600 \mathrm{~s}$ ).

As during these treatments, the sole active metallurgical mechanism is recovery (no recrystallization), these measurements can serve to monitor the evolution of the dislocation density in a reliable way. The flow stress of deformed ferrite can be estimated thanks to the Taylor's model (forest hardening) [31]:

$$
\sigma=\sigma_{\text {micro }}+\alpha M \mu b \sqrt{\rho}
$$

With $\alpha=0.4, \mathrm{M}=3$ the Taylor coefficient, $\mu=82 \mathrm{GPa}$ the shear modulus, $\mathrm{b}=2.5 \times 10^{-10} \mathrm{~m}$ the magnitude of the Burgers vector. Here $\sigma_{\text {micro }}$ accounts for friction stress and Hall Petch strengthening effect. The contribution of dislocation density is estimated with the forest hardening. Indeed, the hardness measurements are conducted after recovery at temperatures and within time ranges during which recrystallization does not occur. The only expected change in the microstructure is the decrease in dislocation density. The grain size and the bulk composition of the ferrite (as a consequence the friction stress) do not evolve during the thermal treatment. Friction stress, grain size and, thus, $\sigma_{\text {micro }}$ remain constant during the annealing at investigated temperature and times.

Then, the flow stress can be related to the hardness thanks to an empirical relationship $\sigma \approx 3 \mathrm{HV}$ [32]. The dislocation density can be calculated as follows:

$$
\sqrt{\rho}=\sqrt{\rho_{C R}}+\frac{3\left(H V-H V_{C R}\right)}{M b}
$$

and $\mathrm{HV}_{\mathrm{CR}}$ the initial hardness in the cold rolled state.

\section{Results and discussion}

The Debye-Scherrer (DS) rings collected of a sample in cold-rolled state are shown in Figure 1 (a). The rings are continuous as expected from a polycrystalline industrial cold-rolled steel. Azimuthal integrations on angular sector between $0^{\circ}$ and $180^{\circ}$ with step $5^{\circ}$ was performed on several images collected from a sample in cold-rolled state as Figure 1 (a) to evaluate the homogeneity of peaks characteristics along the DS rings. The standard deviation of the HWHM of the peaks is about $3 \%$ and the one of $2 \theta_{0}$ is $0.02 \%$. Thus, HWHM and $2 \theta_{0}$ are considered stable along the rings. We also performed the mWH method on each sector and found a standard deviation of the evaluated dislocation density about $3 \%$. The DS rings collected after holding at $550{ }^{\circ} \mathrm{C}$ for $10 \mathrm{~min}$ are shown on Figure 1 (b) and the rings are still continuous. Conversely, after holding at $650{ }^{\circ} \mathrm{C}$ for $10 \mathrm{~min}$, the DS rings are no more continuous but made of bright spots as shown in Figure 1 (c). Those spots are more visible and indicated by red arrows on Figure 1 (d), which is an enlargement of Figure 1 (c). These isolated spots with high intensity on DS rings are due to new individual recrystallized grains [4], [14], [33]-[35]. The high intensity of recrystallization spots may conduct to detector saturation. Thus, the diffraction peaks obtained by integration of rings are affected in turn.

The intensity on the collected diffraction pattern are azimuthally integrated. Then, the obtained 1D diffractograms are fitted as described in previous section. Figure 2 (a) and (b) show the non-corrected HWHM of each studied peak during the thermal treatments after a fast heating $\left(100{ }^{\circ} \mathrm{C} / \mathrm{s}\right)$ and slow heating $\left(3^{\circ} \mathrm{C} / \mathrm{s}\right)$ respectively. The blue, green, orange and red curves correspond to the measurements for thermal treaments at $450{ }^{\circ} \mathrm{C}, 500{ }^{\circ} \mathrm{C}, 550{ }^{\circ} \mathrm{C}$ and $650^{\circ} \mathrm{C}$ respectively. Heating starts at $0 \mathrm{~s}$ by convention. 


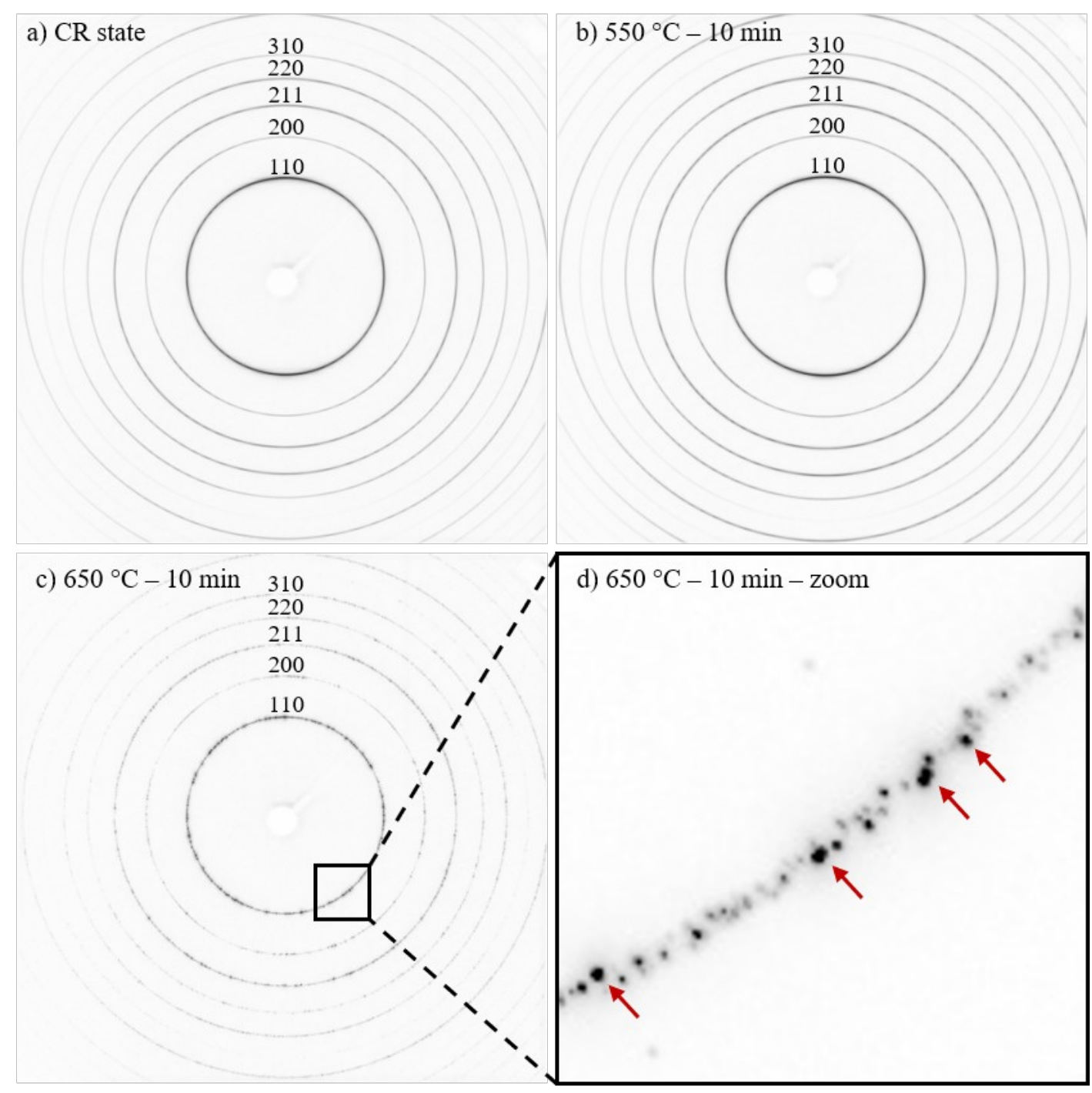

Figure 1: Debye-Scherrer rings of a sample in cold-rolled state (a), after 10 min hold at $550{ }^{\circ} \mathrm{C}$ (b) and at $650{ }^{\circ} \mathrm{C}$ (c). Spots due to recrystallization can be observed at $650{ }^{\circ} \mathrm{C}$ and are indicated by red arrows on the zoom of DS rings collected after $10 \mathrm{~min}$ at $650^{\circ} \mathrm{C}$.

Before heating starts, i.e. when $\mathrm{t}<0 \mathrm{~s}$ in Figure 2 (a) and (b), the values of HWHM of a given peak do not vary much from one sample to another. Conserning the samples heated at $3{ }^{\circ} \mathrm{C} / \mathrm{s}$, the gap between the values of $\mathrm{HWHM}$ estimated in the sample heated at $650^{\circ} \mathrm{C}$ and the others may be due to the experimental set (slight different position of the sample requiring a new calibration).

During the annealings at a temperature between $450^{\circ} \mathrm{C}$ and $550^{\circ} \mathrm{C}$, after heating starts, the HWHM of all studied peak decreases until a saturation. Concerning the annealing at $650{ }^{\circ} \mathrm{C}$, the HWHM drops and, beyond $50 \mathrm{~s}$ after fast heating and $30 \mathrm{~s}$ after slow heating, follows a more chaotic behavior because recrystallization occurs (Figure 1 (c) and (d)). As discussed above, the diffraction peaks obtained by integration of rings are affected in turn.

The peak broadening may be due to several crystallographic features as crystallite size, dislocation density, tetragonality or a distribution of internal or residual stresses (related to non-uniform lattice parameter). No tetragonality is expected in such a low-carbon steel. The cold-rolling process is the only mechanical process applied to the material and as the steel is single-phased, negligible residual 
stress is expected. Finally, the variation of HWHM along the annealing is interpreted only as a variation of crystallite size and dislocation density deconvoluted by the mWH method.

Crystallite sizes and dislocation densities $\rho$ were deduced from equation (2). The crystallite sizes were found to be stable around $17 \mathrm{~nm}$ regardless of annealing temperature or heating rate. This value is consistent with literature [25], [26], [36].

It is difficult to relate the cristallite size to a measurable metallurgical feature. TEM investigations could have been performed as done by Ungar et al. in 2001 [37], for instance, in silicon nitride and copper to confirm the order of magnitude of distributions but TEM results depend strongly on the method used (at least for bulk and heavily deformed metals) as it requires to detect very low angle boundaries. Finally, the key point in our observations is that the mean crystallite size was found stable during the different annealing schedule and, thus, the peak broadening variation is though to be mainly due to the recovery of dislocation density.

a)
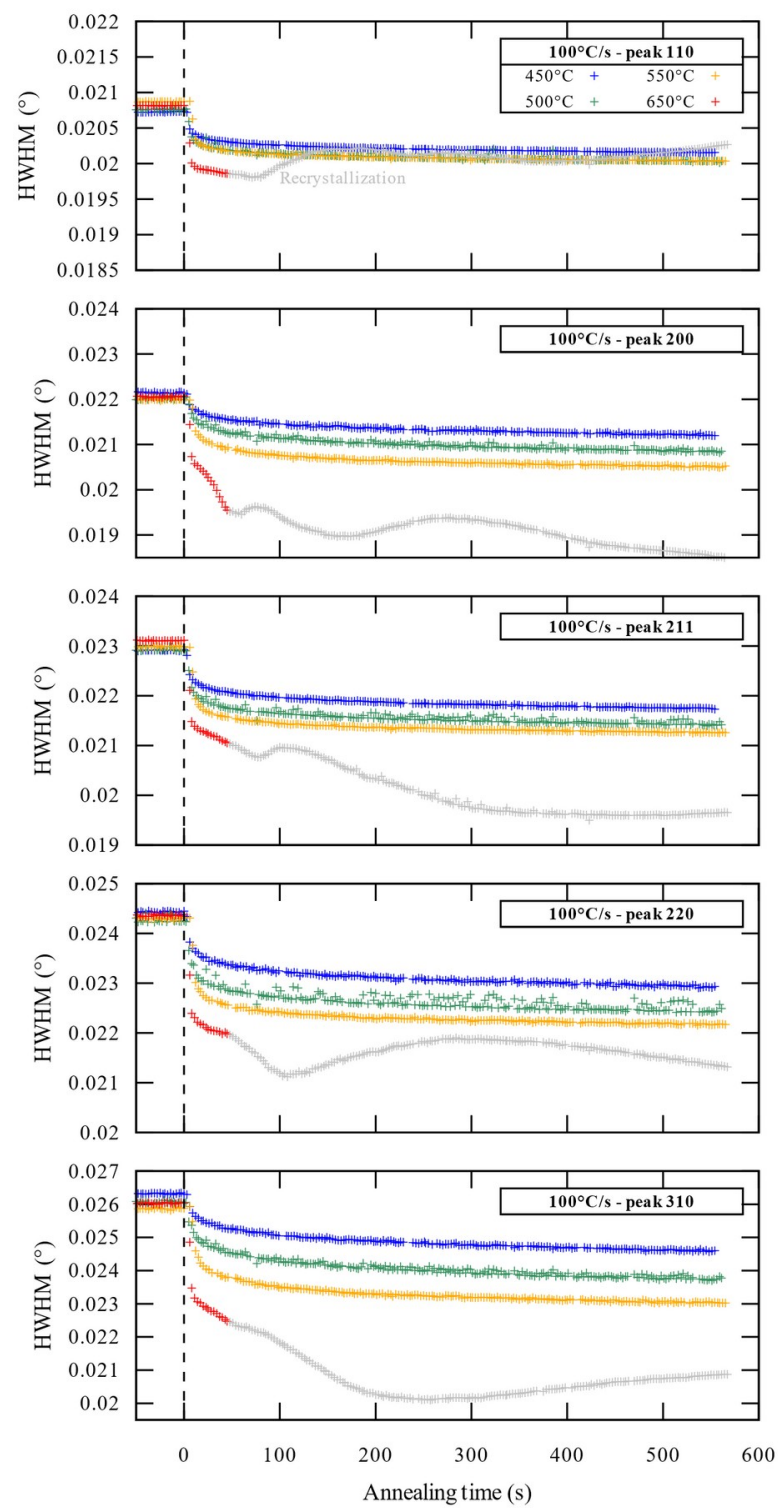

b)
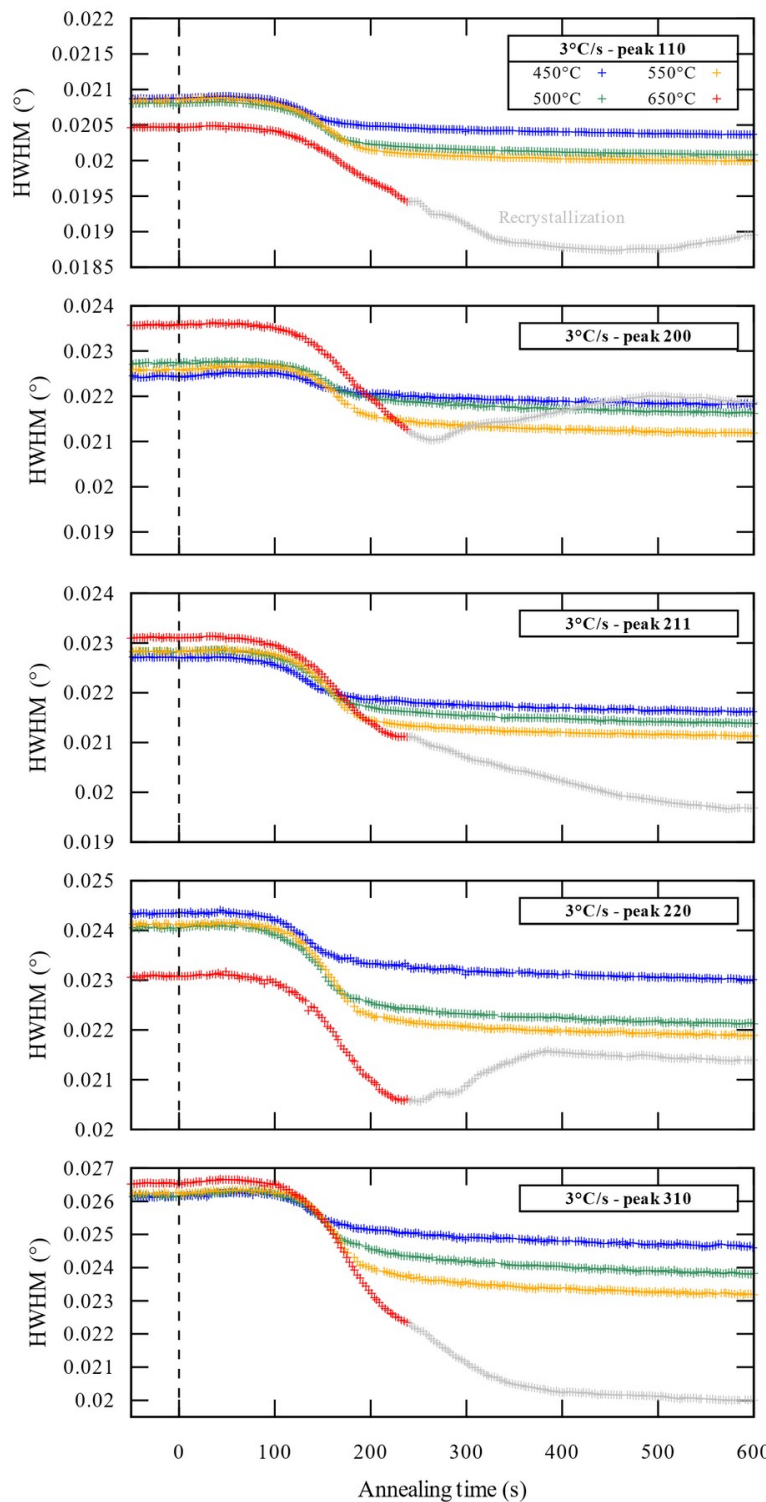

Figure 2: HWHM $\left({ }^{\circ}\right)$ of each studied diffraction peak during annealing at $450{ }^{\circ} \mathrm{C}$ (blue), $500{ }^{\circ} \mathrm{C}$ (green), $550{ }^{\circ} \mathrm{C}$ (orange) and $650{ }^{\circ} \mathrm{C}$ (red) after a) fast heating $\left(100{ }^{\circ} \mathrm{C} / \mathrm{s}\right)$ or b) slow heating $\left(3^{\circ} \mathrm{C} / \mathrm{s}\right)$. 
The dislocation densities $\rho$ are plotted as a function of time for $S=0.5$ in Figure 3. Figure 3 (a) and (b) correspond to the thermal treatments after a fast heating $\left(100{ }^{\circ} \mathrm{C} / \mathrm{s}\right)$ and slow heating $\left(3^{\circ} \mathrm{C} / \mathrm{s}\right)$ respectively. The blue, green, orange and red curves correspond to the measurements for thermal treaments at $450{ }^{\circ} \mathrm{C}$, $500{ }^{\circ} \mathrm{C}, 550^{\circ} \mathrm{C}$ and $650{ }^{\circ} \mathrm{C}$ respectively. Heating starts again at $0 \mathrm{~s}$.

Before heating starts ( $\mathrm{t}<0 \mathrm{~s}$ on Figure 3 (a) and (b)), the values of $\rho$ range between $1.70 \times 10^{15} \mathrm{~m} \cdot \mathrm{m}^{-3}$ and $1.96 \times 10^{15} \mathrm{~m} \cdot \mathrm{m}^{-3}$, which corresponds to the value predicted by micromechanical calculations $\rho_{0}=1.9 \times 10^{15}$ $\mathrm{m} \cdot \mathrm{m}^{-3}$. The error on the dislocation densities has been evaluated at $\pm 7 \times 10^{13} \mathrm{~m} \cdot \mathrm{m}^{-3}$ by calculating the standard deviation of estimated dislocation densities at room temperature. The values of $\rho$ do not vary much from one sample to another. The greater values of $\rho$ estimated in the sample then heated at $650^{\circ} \mathrm{C}$ in slow heating may be due to the experimental set (slight different position of the sample requiring a new calibration).

Concerning the annealing at $650{ }^{\circ} \mathrm{C}$, the dislocation densities have not been studied beyond $50 \mathrm{~s}$ after fast heating and $30 \mathrm{~s}$ after slow heating because recrystallization occurs. As discussed above, recrystallization affects the HWHM of diffraction and our method becomes invalid due to isolated spots on DS rings.

The stability of the HWHM (Figure 2) and dislocation density (Figure 3) before heating shows the robustness of the method.

a)

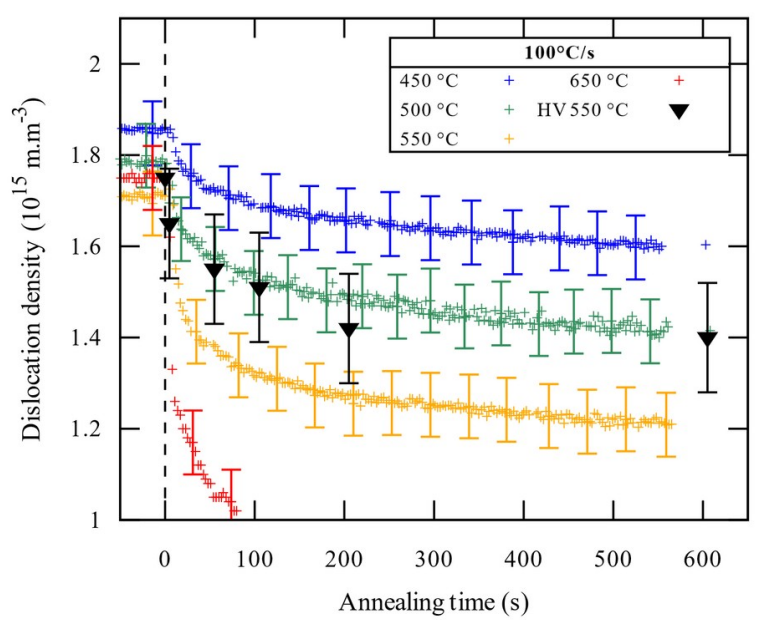

b)

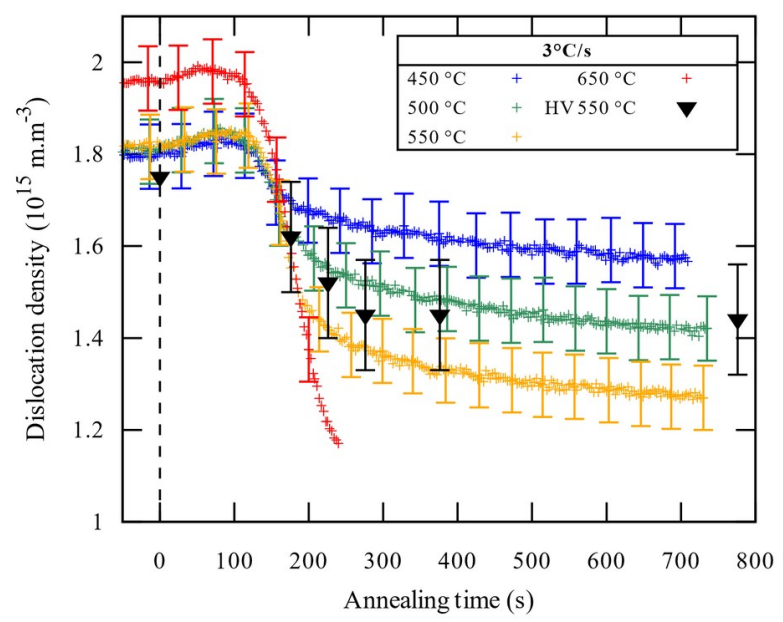

Figure 3: Dislocation densities during annealing at $450{ }^{\circ} \mathrm{C}$ (blue), $500^{\circ} \mathrm{C}$ (green), $550{ }^{\circ} \mathrm{C}$ (orange) and $650{ }^{\circ} \mathrm{C}$ (red) after a) fast heating $\left(100^{\circ} \mathrm{C} / \mathrm{s}\right)$ or b) slow heating $\left(3^{\circ} \mathrm{C} / \mathrm{s}\right)$. Dislocation densities deduced from Vickers hardness tests during annealing at $550{ }^{\circ} \mathrm{C}$ are represented by black triangles.

In the following, the evolution of the dislocation densities during heating and holding is studied in the relative way through $\Delta \rho$, the difference between $\rho$ at a given instant and $\rho_{\mathrm{CR}}$, the initial dislocation density in the studied sample (as-cold-rolled state CR). Figure 4 shows $\Delta \rho$ during the fast (a) and slow (b) heating stage. The end of heating is indicated by dashed lines of the corresponding color of annealing temperature reached. 
a)

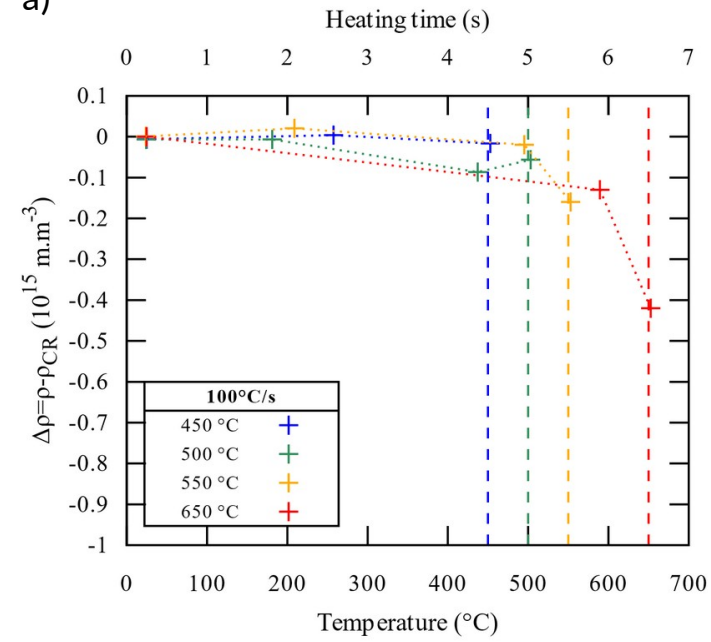

b)

Heating time (s)

$\begin{array}{llllllllll}0 & 25 & 50 & 75 & 100 & 125 & 150 & 175 & 200 & 225\end{array}$

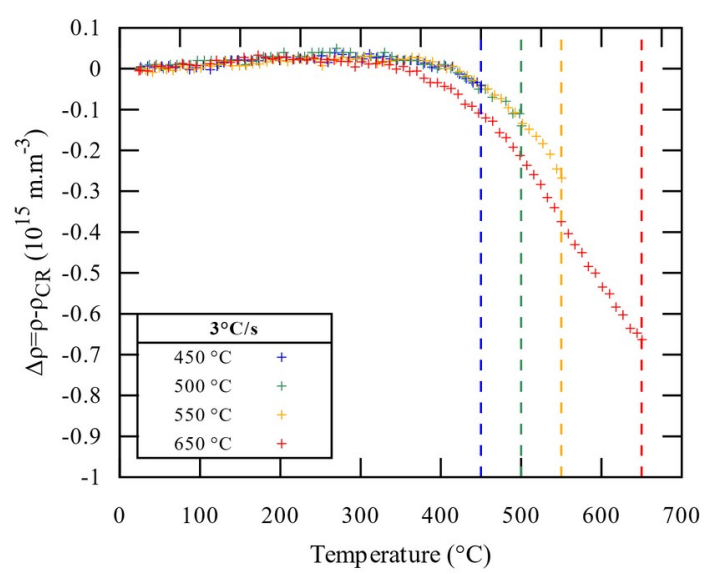

Figure 4: Variation of dislocation densities from the cold-rolled state during the fast (a) and slow (b) heating stages. Vertical dashed lines indicate the end of heating stage depending on the annealing temperature $-450{ }^{\circ} \mathrm{C}$ in blue, $500{ }^{\circ} \mathrm{C}$ in green, $550{ }^{\circ} \mathrm{C}$ in orange and $650{ }^{\circ} \mathrm{C}$ in red.

For all studied treatments, $\Delta \rho$ decreases during the heating stage. For treatments with high heating rate, $\Delta \rho$ slightly decreases and the aquisition rate makes the determination of a transition temperature imprecise. On the contrary, during slow heating, $\Delta \rho$ starts to significantly fall down around $400^{\circ} \mathrm{C}$.

During heating, recovery starts when the samples reach $300^{\circ} \mathrm{C}$ (Figure 4). At the end of the fast heating stage, $\Delta \rho$ equals $-0.02 \times 10^{15} \mathrm{~m} \cdot \mathrm{m}^{-3},-0.06 \times 10^{15} \mathrm{~m} \cdot \mathrm{m}^{-3},-0.16 \times 10^{15} \mathrm{~m} \cdot \mathrm{m}^{-3}$ and $-0.42 \times 10^{15} \mathrm{~m} \cdot \mathrm{m}^{-3}$, when the respective sample reach $450{ }^{\circ} \mathrm{C}, 500{ }^{\circ} \mathrm{C}, 550{ }^{\circ} \mathrm{C}$ and $650{ }^{\circ} \mathrm{C}$. Likewise, $\Delta \rho$ equals $-0.04 \times 10^{15} \mathrm{~m} . \mathrm{m}^{-3}$, $-0.14 \times 10^{15} \mathrm{~m} \cdot \mathrm{m}^{-3},-0.27 \times 10^{15} \mathrm{~m} \cdot \mathrm{m}^{-3}$ and $-0.66 \times 10^{15} \mathrm{~m} \cdot \mathrm{m}^{-3}$ at the end of the slow heating stage.

a)

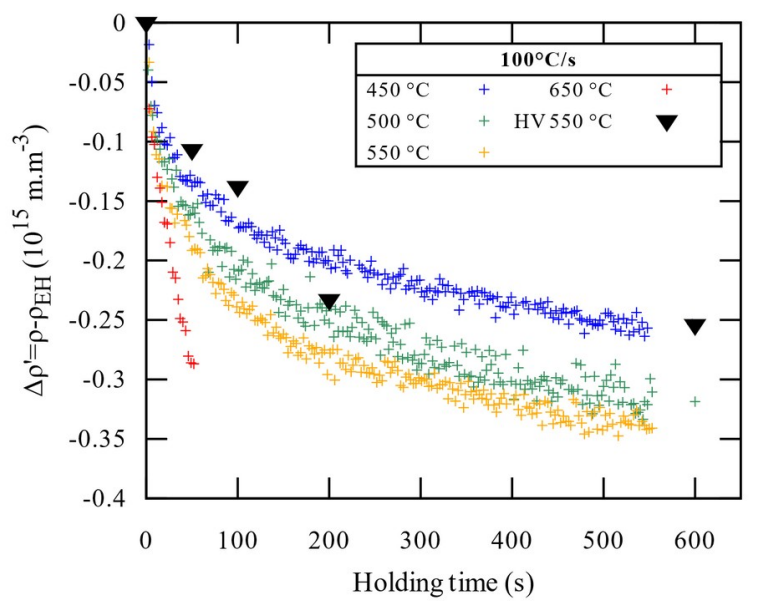

b)

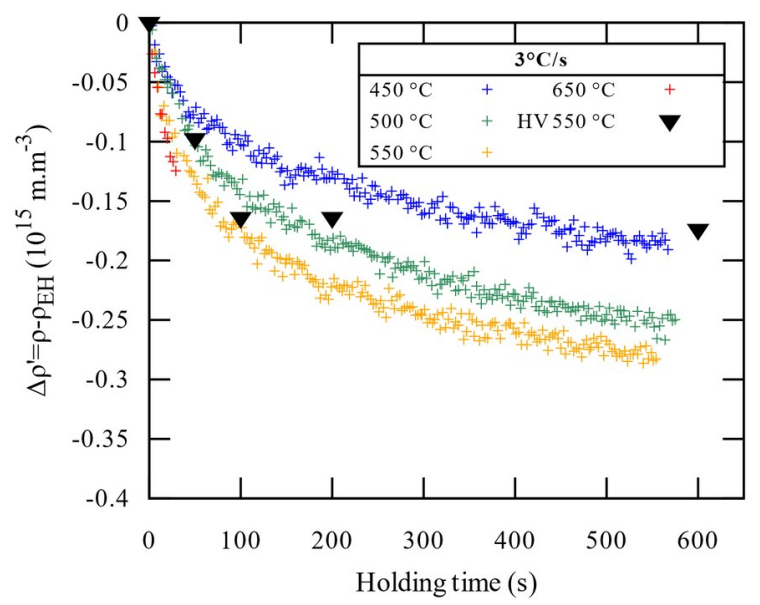

Figure 5 : Variation of dislocation densities from the end of heating stage during the holding at $450{ }^{\circ} \mathrm{C}$ in blue, $500{ }^{\circ} \mathrm{C}$ in green, $550{ }^{\circ} \mathrm{C}$ in orange and $650{ }^{\circ} \mathrm{C}$ in red after fast (a) and slow (b) heating. Variation of dislocation densities deduced from Vickers hardness tests during holding at $550{ }^{\circ} \mathrm{C}$ are represented by black triangles. 
The recovery during holding stage is studied through $\Delta \rho$ ', the difference between $\rho$ at a given instant and $\rho_{\mathrm{EH}}$, the dislocation density in the studied sample at the end of the heating stages of the eight experiments.

Figure 5 shows $\Delta \rho$ ' during the holding stage. During holding, $\Delta \rho$ ' drops significantly at first and then tends to a saturation behavior. First, the initial slope slightly decreases by increasing the holding temperature. Then, the slope decreases with time until a saturation which is not reached here. The higher the holding temperature, the lower the saturation. Finally, Figure 3 (a) and (b) show that holding at a given temperature yields to a given decay in dislocation density, independently of the heating rate. This behavior is very similar for both heating rates with a relative decrease more pronounced after fast heating. The saturation behavior has already been observed by indirect methods such as hardness, ceorcive field or resistivity measurements [6], [38], [39].

Currently, two mechanisms have been identify as probable origin for the saturation of the recovery. First possibility, the initial drop in dislocation density could be due to fast annihilation of "free" untangled dislocations. Then, recovery continues by reorganization of tangled dislocations defining cell boundaries and cell growth, following a much slower mechanism. This leads to a very slow recovery difficult to differentiate from a saturating behavior [7]. It is also likely that this observed behavior comes from a texture effect, related to the two main fibers $\alpha$ and $\gamma$. The cold-rolling process is expected to introduce higher dislocation densities in grains belonging to fiber $\gamma$, which recovers rapidly at the beginning of the annealing. Lower dislocation densities are expected in grains belonging to fiber $\alpha$. The lower driving force leads to a slower and later recovery, which could explain the second recovery step [9], [40]. However, the observed trend in temperatures pleads in favor of the first mechanism.

After the fast heating, $\Delta \rho^{\prime}$ stabilizes around $-0.23 \times 10^{15} \mathrm{~m} \cdot \mathrm{m}^{-3},-0.31 \times 10^{15} \mathrm{~m} \cdot \mathrm{m}^{-3}$ and $-0.34 \times 10^{15} \mathrm{~m} \cdot \mathrm{m}^{-3}$ during annealing at $450^{\circ} \mathrm{C}, 500^{\circ} \mathrm{C}$ and $550^{\circ} \mathrm{C}$ respectively (Figure 5 (a)). After the slow heating, $\Delta \rho$ ' stabilizes around $-0.19 \times 10^{15} \mathrm{~m} \cdot \mathrm{m}^{-3},-0.25 \times 10^{15} \mathrm{~m} \cdot \mathrm{m}^{-3}$ and $-0.28 \times 10^{15} \mathrm{~m} \cdot \mathrm{m}^{-3}$ during annealing at $450^{\circ} \mathrm{C}$, $500^{\circ} \mathrm{C}$ and $550^{\circ} \mathrm{C}$ respectively. $\Delta \rho^{\prime}$ reaches $-0.28 \times 10^{15} \mathrm{~m} . \mathrm{m}^{-3}$, i.e. $\rho=1.05 \times 10^{15} \mathrm{~m} . \mathrm{m}^{-3}$, after fast heating and $50 \mathrm{~s}$ at $650{ }^{\circ} \mathrm{C}$ and $-0.12 \times 10^{15} \mathrm{~m} \cdot \mathrm{m}^{-3}$, i.e. $\rho=1.15 \times 10^{15} \mathrm{~m} \cdot \mathrm{m}^{-3}$, after slow heating and $30 \mathrm{~s}$ at $650{ }^{\circ} \mathrm{C}$, just before recrystallization starts.

Table 2 shows the average hardness (HV 0.5) measured on samples after interrupted treatments $(0 \mathrm{~s}, 50 \mathrm{~s}$, $100 \mathrm{~s}, 200 \mathrm{~s}$ and $600 \mathrm{~s}$ ). Six measurements were performed on each samples. The error is estimated at \pm $10 \mathrm{HV}$, the maximum standard deviation of the hardness measured on a sample.

Table 2: Average hardness (HV 0.5) in the cold rolled state, after heating at $3{ }^{\circ} \mathrm{C} / \mathrm{s}$ or $100{ }^{\circ} \mathrm{C} / \mathrm{s}$ and $0 \mathrm{~s}, 50 \mathrm{~s}$, $100 \mathrm{~s}, 200 \mathrm{~s}$ or $600 \mathrm{~s}$ at $550{ }^{\circ} \mathrm{C}$.

\begin{tabular}{ccccccc}
$\begin{array}{c}\text { Holding } \\
\text { time }\end{array}$ & CR & $0 \mathrm{~s}$ & $50 \mathrm{~s}$ & $100 \mathrm{~s}$ & $200 \mathrm{~s}$ & $600 \mathrm{~s}$ \\
\hline \hline $100^{\circ} \mathrm{C} / \mathrm{s}$ & 236 & 229 & 220 & 217 & 209 & 207 \\
$3^{\circ} \mathrm{C} / \mathrm{s}$ & 225 & 217 & 212 & 212 & 211
\end{tabular}

The dislocation densities determined by hardness measurements and equation (5) are represented by black triangles on Figure 3 and Figure 5. Considering the error on the hardness measurements and equation 5, the error on dislocation densities estimated by hardness measurements is about $0.12 \times 10^{15} \mathrm{~m} \cdot \mathrm{m}^{-3}$. The dislocation density in the cold rolled state $\rho_{\mathrm{CR}}$ is estimated at $1.75 \times 10^{15} \mathrm{~m} \cdot \mathrm{m}^{-3}$, i.e. the average of the values obtained by HEXRD on samples heated at $550{ }^{\circ} \mathrm{C}$. The longer the holding time is, the lower the dislocation density is. The dislocation density falls down to $1.4 \times 10^{15} \mathrm{~m} \cdot \mathrm{m}^{-3}$ after holding $600 \mathrm{~s}$ holding at $550{ }^{\circ} \mathrm{C}$. In addition, a stabilization occurs, since the dislocation density decreases only about $0.02 \times 10^{15} \mathrm{~m} \cdot \mathrm{m}^{-3}$ during the last $400 \mathrm{~s}$, regardless of the heating rate. As it can be seen on Figure 3 and Figure 5, those densities and the corresponding $\Delta \rho$ ' are of the same order as the ones determined by HEXRD and follow the same 
decreasing trend. The saturation of dislocation recovery observed by HEXRD is thus confirmed by hardness measurements.

Thus, recovery starts during the heating ramp when temperature is about $300{ }^{\circ} \mathrm{C}$ and leads to a drop in dislocation density. This drop quickly slows down when isothermal holding starts until reaching a saturation. Heating conditions are of great importance for the control of recovery process, which starts at low temperature - about $300{ }^{\circ} \mathrm{C}$ - and is faster during heating stage than during holding stage.

The dislocation densities shown in Figure 3 were computed considering $S=0.5$, i.e. edge and screw dislocations are present with equal probability. The same study has been carried out considering $S=0$, i.e. only edge dislocations, and $\mathrm{S}=1$, i.e. only screw dislocations.

The proportion of screw dislocation $S$ influences the alignment of couples $\mathrm{K}^{2} \mathrm{C}-\Delta \mathrm{K}$. As $\mathrm{S}$ decreases from 1 to $0, \mathrm{~K}^{2} \mathrm{C}-\Delta \mathrm{K}$ points tend to align. Moreover, the slope of the linear regression decreases as $\mathrm{S}$ increase from 0 to 1 . Then, according to (2), $\mathrm{S}$ increasing from 0 to 1 tends to lower the estimated dislocation density and a constant relative gap of $8 \%$ is observed at all studied temperatures all along the treatments. No significant effect of $\mathrm{S}$ is noted on crystallite sizes.

Although linear regressions of couples $K^{2} C-\Delta K$ get $R^{2}$ scores closer to 1 when $S$ tends to $0, S$ cannot be considered equal to 0 . According to literature, dislocations in deformed ferrite are rather screws [28], [41]. Thus, $\mathrm{S}$ would be greater that 0.5 . However, this proportion is hard to estimate experimentally. This is why, $\mathrm{S}$ is often set to 0.5 [23], [26].

It is crucial to remind that the value of $R_{e}$ has been manually fitted with $S=0$ so that the dislocation densities in as cold-rolled state correspond to the one estimated by micromechanical calculations. This value has been used with $\mathrm{S}=0.5$ and $\mathrm{S}=1$ too. Thus, the influence of $\mathrm{S}$ has been shown. However, the dislocation density predicted by micromechanical calculations may be reached in as cold-rolled state by using $R_{e}=8.3 \mathrm{~nm}$ with $S=0.5$ and $R_{e}=7.9 \mathrm{~nm}$ with $S=1$. The order of magnitude of $R_{e}$ is still respected. The classical models for recovery, such as the climb or cross-slip models of Friedel [42] or the solute drag model of Nes [7], cannot reproduce both slope and saturation reached, even if major alloying elements leading to solute drag (carbon [43]-[45], manganese [4], [45], [46] or chromium [47]) are accounted for (the reader can refer to appendix C. for more details). Except empirical models such as [48] in which a saturation is explicitly introduced, the saturation is not yet explained in the literature. However, these models fit well and thus may explain the initial drop. After this initial stage of recovery, the leading mechanism seems thermally activated during heating (sensitive to heating rate) and then solely governed by temperature during holding (no memory effect). During this stage, dislocation cells may form and pinning may hinder dislocations mobility. It may be necessary to consider different dislocation densities (isolated dislocations, growing cell/subgrain structures) and to introduce cell growth models such as [49].

\section{Conclusion}

Recovery by annihilation during intercritical annealing of a cold-rolled ferritic steel was studied in situ by HEXRD. Dislocation densities were determined from HEXRD experiments by implementing modified Williamson-Hall method [24], [26].

Debye-Scherrer rings were azimutally integrated. Diffraction peaks were individually modelled by a Peason VII function, giving HWHM among other parameters. The HWHM was quadratically corrected from instrumental braodening. However, this correction had no significant effect on the final dislocation densities. Contrast factors were computed as a function of temperature using the work of Ghosh and Oslon [30] and dislocation type - through the parameter S. Micromechanical calculations gave an estimation of dislocation density in as cold-rolled state and a calibration of the cut-off radius $R_{e}$, set at $8.5 \mathrm{~nm}$. The estimation of dislocation density lowers slightly when $\mathrm{S}$ increases from 0 to 1 . Linear regressions led to choose $\mathrm{S}=0$ in spite of literature predicting $\mathrm{S}>0.5$ in deformed ferrite. Thus, the parameter $\mathrm{S}$ has been set to 0.5 . 
For each studied treatment, the values of dislocation density had few scattering and reasonnable continuity. Recovery was actually observed, as well as recrystallization during annealing at $650{ }^{\circ} \mathrm{C}$. During fast heating, dislocation density has shown a drop followed by a saturation behavior during holding. The classical models for recovery cannot reproduce both slope and saturation level.

\section{Acknowledgements}

This work was supported by the French State through the program "Investment in the future" operated by the National Research Agency (ANR) and referenced by ANR-11-LABX-0008-01 (LabEx DAMAS).

This work was funded by ArcelorMittal Maizières-lès-Metz (Product Research Centre), by the Université de Lorraine, by the CNRS (Centre National de la Recherche Scientifque) and the French ANRT (Agence Nationale de la Recherche et de la Technologie) under the CIFRE convention (2020/1022). The HEXRD experiments were conducted at DESY (PETRA III-P07 beamline) in Hamburg. Special thanks is dedicated to the team of the P-07 line (N.Schell). Their expertise was appreciated and widely contributed to the success of the study.

\section{Conflicts of Interest}

The authors declare no conflict of interest. The funders had no role in the design of the study; in the collection, analyses, or interpretation of data; in the writing of the manuscript, or in the decision to publish the results.

\section{Data availability}

The raw/processed data required to reproduce these findings cannot be shared at this time as the data also forms part of an ongoing study. 


\section{Appendices}

\section{A. Contrast factor dependency with temperature}

For a given temperature, the elastic constants calculated as shown in appendix B., are put in the algorithm ANISC [29], which computes the contrast factors for each studied diffraction peak and a given dislocation type (edge or screw).

First, the contrast factors $C^{E}{ }_{110}, C^{E}{ }_{200}, C^{E}{ }_{211}, C^{E}{ }_{220}$ and $C^{E}{ }_{310}$ are calculated considering edge dislocations, whose slipping system is $<1,1,1>\{1,1,0\}$. Then, the contrast factors $C_{110}^{S}, C_{200}^{S}, C_{211}^{S}, C_{220}^{S}$ and $C_{310}^{S}$ are calculated considering screw dislocations, whose slipping system is $\langle 1,1,1>$. Considering the diffraction plane (200), $H^{2}=\frac{h^{2} k^{2}+h^{2} l^{2}+k^{2} l^{2}}{h^{2}+k^{2}+l^{2}}$ equals 0. Thus, (3) gives :

$$
\begin{aligned}
& C_{h 00}^{E}=C_{200}^{E} \\
& C_{h 00}^{S}=C_{200}^{S}
\end{aligned}
$$

Considering the diffraction plane (110), $H^{2}=\frac{h^{2} k^{2}+h^{2} l^{2}+k^{2} l^{2}}{h^{2}+k^{2}+l^{2}}$ equals $\frac{1}{4}$. Thus, (3) gives :

$$
\begin{aligned}
& q^{E}=4\left(1-\frac{C_{110}^{E}}{C_{h 00}^{E}}\right) \\
& q^{S}=4\left(1-\frac{C_{110}^{S}}{C_{h 00}^{S}}\right)
\end{aligned}
$$

Finally, Eq (B.1) and Eq (B.2) give $C_{h 00}^{E}, C_{h 00}^{S}, q^{E}$ et $q^{S}$ for equation (3).

\section{B. Elastic constants dependency with temperature}

The elastic constants of ferrite has been calculated using the empirical Ghosh and Olson's model [30]. The $\alpha$ ferrite is supposed isotropic. The bulk modulus $B=\frac{C_{11}+2 C_{12}}{3}$ is given in GPa by:

$$
B=171.87\left[1-0.28029\left(\frac{T}{T_{C}}\right)^{2}+0.07221\left(\frac{T}{T_{C}}\right)^{3}\right] \quad \text { Eq (A.1.) }
$$

With $\mathrm{T}$ the temperature in $\mathrm{K}$ and $\mathrm{T}_{\mathrm{C}}=1043 \mathrm{~K}$ the Curie's temperature of $\alpha$ iron. Likewise, the shear modulus $\mu=C_{44}(\mathrm{GPa})$ of a polycrystal is given by:

$$
\mu=84.07\left[1-0.48797\left(\frac{T}{T_{C}}\right)^{2}+0.12651\left(\frac{T}{T_{C}}\right)^{3}\right]
$$

By considering the anisotropy factor $A=\frac{2 C_{44}}{C_{11}-C_{12}}$ of $\alpha$, estimated at 2.5 [50], the elastic constants $\mathrm{C}_{11}$, $\mathrm{C}_{12}$ and $\mathrm{C}_{44}$ can be evaluated for temperatures between $27^{\circ} \mathrm{C}(300 \mathrm{~K})$ and $650{ }^{\circ} \mathrm{C}$.

\section{Modeling recovery}

Friedel's model of recovery is based on mechanical relaxation approach [42]. Cross slipping or climbing were considered principal mechanisms for dislocation mobility.

Considering cross slipping as main mechanisms for dislocation mobility, the variation of dislocation density is written:

$$
\frac{d \rho}{d t}=-K \frac{2 \sqrt{\rho}}{\alpha M \mu b} \exp \left(\frac{-U_{0}+V \alpha M \mu b \sqrt{\rho}}{k T}\right)
$$


where $\rho\left(\mathrm{m} \cdot \mathrm{m}^{-3}\right)$ is the dislocation density, $\mathrm{K}\left(\mathrm{J} \cdot \mathrm{GPa}^{-2} \mathrm{~s}^{-1}\right)$ is a constant, $\mu$ (MPa) is the shear modulus, $\mathrm{M}$ (s.d.) is the Taylor coefficient link to the microstructure, $b(\mathrm{~m})$ is the magnitude of Burgers vector, $\mathrm{U}_{0}(\mathrm{~J})$ is the activation energy, $\mathrm{V}\left(\mathrm{m}^{3}\right)$ is the activation volume, $\mathrm{k}$ is the Boltzmann's constant, $\mathrm{t}(\mathrm{s})$ is time and $\mathrm{T}(\mathrm{t})$ $(\mathrm{K})$ is the current temperature during the treatment. This model was implemented by Moreno [4] and did not achieve a satisfying agreement.

Considering climbing as main mechanisms for dislocation mobility, equation (C.1) becomes:

$$
\frac{d \rho}{d t}=-K \frac{2(\alpha M \mu b \rho)^{2}}{k T} \exp \left(\frac{-U_{0}+V \alpha M \mu b \sqrt{\rho}}{k T}\right) \quad \text { Eq (C.2) }
$$

The constant $\alpha$ has been set at 0.15 and $M$ at 3 [4]. The magnitude of Burgers vector in ferrite is $b=2.5 \times 10^{-}$ ${ }^{10} \mathrm{~m}$. The shear modulus is calculated thanks to equation A.2.

The constant $\mathrm{K}$, the activation energy $\mathrm{U}_{0}$ and the activation volume $\mathrm{V}$ were considered as fitting parameters. These calibration parameters were fitted using Scipy library.

The results of the model $\mathrm{K}=2.310^{-16} \mathrm{~J} . \mathrm{GPa}^{-2} \cdot \mathrm{s}^{-1}, \mathrm{U}_{0}=182 \mathrm{~kJ} \cdot \mathrm{mol}^{-1}$ and $\mathrm{V}=23 \mathrm{~b}^{3}$ (solid line) obtained on treatments with fast heating rate $\left(100^{\circ} \mathrm{C} / \mathrm{s}\right)$ and consistent with literature [4], [8], [51], [52] are compared to experimental data (crosses) on Figure C. 1 . The inability of the model to capture the experimental trends is obvious.

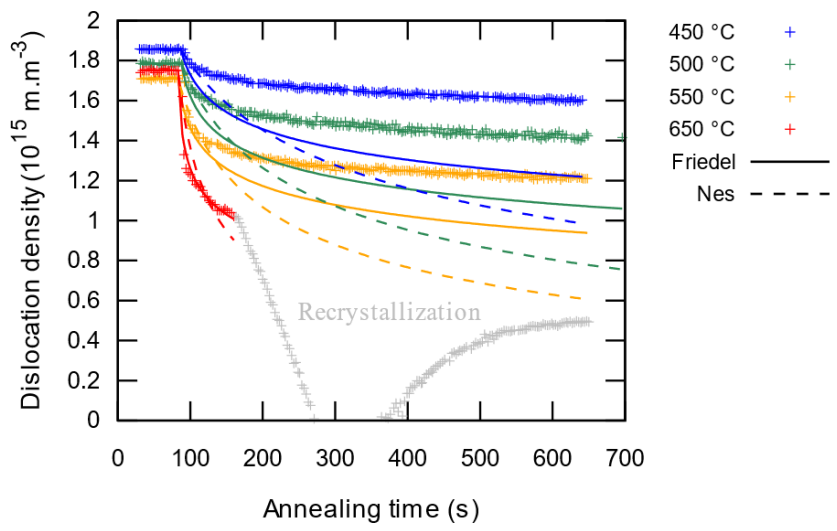

Figure C. 1: Dislocation density during annealing at $450{ }^{\circ} \mathrm{C}$ (blue), $500{ }^{\circ} \mathrm{C}$ (green), $550{ }^{\circ} \mathrm{C}$ (orange) and $650^{\circ} \mathrm{C}$ (red) after fast heating $\left(100^{\circ} \mathrm{C} / \mathrm{s}\right)$. Dislocation densities deduced from experiments, Friedel's model and Nes' model are respectively plotted with crosses, solid line and solid line.

The Nes' model for solute drag [7] has been implemented. This model considers solute drag as the ratecontrolling mechanism for recovery of a dislocation net of size $r$. The alloying elements of the studied steel, such as carbon, manganese and chromium, may be at the origin of such solute drag effect [43]-[47].

By approximating the dislocation density as $\rho \approx 1 / \mathrm{r}^{2}$, the evolution of the dislocation density can be written:

$$
\frac{\partial r}{\partial t}=\frac{-1}{2} \rho^{\frac{-3}{2}} \frac{\partial \rho}{\partial t}=C^{\prime} v \quad \text { Eq (C.3) }
$$

Where $C^{\prime}$ is a constant to fit and $v$ is the average migration rate of dislocations. This migration is due to the driving force:

$$
F=\frac{\alpha M \mu b^{2}}{r}=\alpha M \mu b^{2} \sqrt{\rho} \quad \text { Eq (C.4) }
$$

With $\mu$ (MPa) is the shear modulus, $M=3$ (s.d.) [4] is the Taylor coefficient, $b=2.5 \times 10^{-10} \mathrm{~m}$ is the magnitude of Burgers vector. The constant $\alpha$ has been set at 0.15 [4]. When dislocations are rate-controlled by solute drag, their migration rate is written: 


$$
v=2 b v_{d} \exp \left(\frac{-Q_{s a}}{R T}\right) \sinh \left(\frac{F b l_{s}}{k T}\right) \quad \text { Eq (C.5) }
$$

Where $v_{d}=6.1510^{13} \mathrm{~Hz}$ is the Debye frequency in iron, $\mathrm{Q}_{\mathrm{sa}}$ is the activation energy for solute diffusion in the matrix and $l_{a}$ is a feature dislocation length between to solute atoms. This length can be calculated with:

$$
l_{s}=\frac{\Omega}{\pi(\kappa b)^{2}} C_{s}^{\frac{-2}{3}} \quad \text { Eq (C.6) }
$$

Where $\Omega=12.1 \AA^{3}$ is the atomic volume of ferrite, $\mathrm{\kappa}$ is a constant defining $\mathrm{kb}$ the maximum interaction length between dislocations and solute atoms and $\mathrm{C}_{\mathrm{s}}$ is solute concentration.

The constants $C$ and $\kappa$ were considered as fitting parameters. The results of the model $C^{\prime}=2.0 \times 10^{-11}$ and $\mathrm{K}=2.8$ (dotted line) obtained on treatments with fast heating rate $\left(100^{\circ} \mathrm{C} / \mathrm{s}\right)$ considering the solute drag effect of carbon are compared to experimental data (crosses) on Figure C. 1 . The trends provided by the model are even worse than the ones obtained with the Friedel's model.

\section{References}

[1] G. R. Speich, V. A. Demarest, et R. L. Miller, «Formation of Austenite During Intercritical Annealing of Dual-Phase Steels », MTA, vol. 12, nº 8, p. 1419-1428, août 1981, doi: 10.1007/BF02643686.

[2] J. Huang, W. J. Poole, et M. Militzer, « Austenite formation during intercritical annealing », Metall and Mat Trans A, vol. 35, nº 11, p. 3363-3375, nov. 2004, doi: 10.1007/s11661-004-0173-x.

[3] M. Ollat, V. Massardier, D. Fabregue, E. Buscarlet, F. Keovilay, et M. Perez, « Modeling of the Recrystallization and Austenite Formation Overlapping in Cold-Rolled Dual-Phase Steels During Intercritical Treatments », Metallurgical and Materials Transactions A, vol. 48, n 10, p. 4486-4499, oct. 2017, doi: 10.1007/s11661-017-4231-6.

[4] M. Moreno, « Metallurgical mechanisms and their interactions during the annealing of coldrolled ferrite-pearlite steels : characterization and modeling », phdthesis, Université de Lorraine, 2019. Consulté le: août 12, 2020. [En ligne]. Disponible sur: https://hal.univ-lorraine.fr/tel-02349113

[5] S. Y. P. Allain, I. Pushkareva, J. Teixeira, M. Gouné, et C. Scott, « Dual-Phase Steels: The First Family of Advanced High Strength Steels ", in Reference Module in Materials Science and Materials Engineering, Elsevier, 2020. doi: 10.1016/B978-0-12-819726-4.00057-0.

[6] F. J. Humphreys et M. Hatherly, Recrystallization and related annealing phenomena, 1st ed. Oxford, OX, UK ; Tarrytown, N.Y., U.S.A: Pergamon, 1995.

[7] E. Nes, « Recovery revisited », Acta Metallurgica et Materialia, vol. 43, nº 6, p. 2189-2207, juin 1995, doi: 10.1016/0956-7151(94)00409-9.

[8] M. Verdier, Y. Brechet, et P. Guyot, « Recovery of AlMg alloys: flow stress and strain-hardening properties », Acta Materialia, vol. 47, $\mathrm{n}^{0}$ 1, p. 127-134, décembre 1998, doi: 10.1016/S13596454(98)00350-4.

[9] M. Oyarzábal, A. Martínez-de-Guerenu, et I. Gutiérrez, « Effect of stored energy and recovery on the overall recrystallization kinetics of a cold rolled low carbon steel », Materials Science and Engineering: A, vol. 485, no 1-2, p. 200-209, juin 2008, doi: 10.1016/j.msea.2007.07.077.

[10] S. Allain, J.-P. Chateau, et O. Bouaziz, «A physical model of the twinning-induced plasticity effect in a high manganese austenitic steel ", Materials Science and Engineering: A, vol. 387-389, p. 143147, décembre 2004, doi: 10.1016/j.msea.2004.01.060.

[11] S. Y. P. Allain, O. Bouaziz, I. Pushkareva, et C. P. Scott, « Towards the microstructure design of DP steels: A generic size-sensitive mean-field mechanical model », Materials Science and Engineering: A, vol. 637, p. 222-234, juin 2015, doi: 10.1016/j.msea.2015.04.017.

[12] I. Pushkareva, S. Allain, C. Scott, A. Redjaïmia, et A. Moulin, «Relationship between Microstructure, Mechanical Properties and Damage Mechanisms in High Martensite Fraction Dual Phase 
Steels », ISIJ International, vol. 55, $\mathrm{n}^{\circ}$ 10, p. 2237-2246, 2015, doi: 10.2355/isijinternational.ISIJINT2015-186.

[13] C. P. Scott, F. Fazeli, B. Shalchi Amirkhiz, I. Pushkareva, et S. Y. P. Allain, « Structure-properties relationship of ultra-fine grained V-microalloyed dual phase steels ", Materials Science and Engineering: A, vol. 703, p. 293-303, août 2017, doi: 10.1016/j.msea.2017.07.051.

[14] M. Moreno et al., «Real-Time Investigation of Recovery, Recrystallization and Austenite Transformation during Annealing of a Cold-Rolled Steel Using High Energy X-ray Diffraction (HEXRD) », Metals, vol. 9, n 1, p. 8, décembre 2018, doi: 10.3390/met9010008.

[15] F. J. Humphreys, «A unified theory of recovery, recrystallization and grain growth, based on the stability and growth of cellular microstructures-I. The basic model ", Acta Materialia, vol. 45, $\mathrm{n}^{\circ}$ 10, p. 4231-4240, oct. 1997, doi: 10.1016/S1359-6454(97)00070-0.

[16] C. Zheng et D. Raabe, «Interaction between recrystallization and phase transformation during intercritical annealing in a cold-rolled dual-phase steel: A cellular automaton model », Acta Materialia, vol. 61, no 14, p. 5504-5517, août 2013, doi: 10.1016/j.actamat.2013.05.040.

[17] A. Chbihi, D. Barbier, L. Germain, A. Hazotte, et M. Gouné, « Interactions between ferrite recrystallization and austenite formation in high-strength steels », Journal of Materials Science, vol. 49, ${ }^{\circ}$ 10, p. 3608-3621, mai 2014, doi: 10.1007/s10853-014-8029-2.

[18] Q. Lai et al., «Mechanism of Austenite Formation from Spheroidized Microstructure in an Intermediate Fe-0.1C-3.5Mn Steel », Metallurgical and Materials Transactions A, vol. 47, n ${ }^{0}$ 7, p. 33753386, juillet 2016, doi: 10.1007/s11661-016-3547-y.

[19] M. Ollat et al., « Mixed-mode model for ferrite-to-austenite phase transformation in dual-phase steel », Computational Materials Science, vol. 149, p. 282-290, juin 2018, doi: 10.1016/j.commatsci.2018.02.052.

[20] S. Allain et O. Bouaziz, « Microstructure based modeling for the mechanical behavior of ferritepearlite steels suitable to capture isotropic and kinematic hardening ", Materials Science and Engineering: A, vol. 496, no 1-2, p. 329-336, nov. 2008, doi: 10.1016/j.msea.2008.06.009.

[21] G. Ashiotis, A. Deschildre, Z. Nawaz, J. P. Wright, D. Karkoulis, et F. E. Picca, « The fast azimuthal integration Python library: pyFAI », p. 10, 2015.

[22] M. A. Branch, T. F. Coleman, et Y. Li, « A Subspace, Interior, and Conjugate Gradient Method for Large-Scale Bound-Constrained Minimization Problems », SIAM J. Sci. Comput., vol. 21, n 1, p. 1-23, janv. 1999, doi: 10.1137/S1064827595289108.

[23] T. Ungár et A. Borbély, «The effect of dislocation contrast on x-ray line broadening: A new approach to line profile analysis ", Applied Physics Letters, vol. 69, n 21 , p. 3173-3175, nov. 1996, doi: 10.1063/1.117951.

[24] T. Ungár, I. Dragomir, Á. Révész, et A. Borbély, « The contrast factors of dislocations in cubic crystals: the dislocation model of strain anisotropy in practice ", Journal of Applied Crystallography, vol. 32, nº 5, p. 992-1002, oct. 1999, doi: 10.1107/S0021889899009334.

[25] T. Ungár, "Microstructural parameters from X-ray diffraction peak broadening », Scripta Materialia, vol. 51, no 8, p. 777-781, oct. 2004, doi: 10.1016/j.scriptamat.2004.05.007.

[26] N. Sallez et al., «In situ characterization of microstructural instabilities: Recovery, recrystallization and abnormal growth in nanoreinforced steel powder ", Acta Materialia, vol. 87, p. 377389, avril 2015, doi: 10.1016/j.actamat.2014.11.051.

[27] S. Takaki, T. Masumura, et T. Tsuchiyama, « Proposal of Simplified Modified Williamson-Hall Equation », ISIJ International, vol. 58, $\mathrm{n}^{\circ}$ 12, p. 2354-2356, décembre 2018, doi: 10.2355/isijinternational.ISIJINT-2018-517.

[28] S. Takaki, T. Masumura, et T. Tsuchiyama, «Dislocation Characterization by the Direct-fitting/modified Williamson-Hall (DF/mWH) Method in Cold Worked Ferritic Steel », ISIJ International, vol. 59, n⿳0 3, p. 567-572, mars 2019, doi: 10.2355/isijinternational.ISIJINT-2018-623.

[29] A. Borbély, J. Dragomir-Cernatescu, G. Ribárik, et T. Ungár, « Computer program ANIZC for the calculation of diffraction contrast factors of dislocations in elastically anisotropic cubic, hexagonal and 
trigonal crystals ", Journal of Applied Crystallography, vol. 36, n 1, p. 160-162, février 2003, doi: $10.1107 /$ S0021889802021581.

[30] G. Ghosh et G. B. Olson, "The isotropic shear modulus of multicomponent Fe-base solid solutions », Acta Materialia, vol. 50, n 10, p. 2655-2675, juin 2002, doi: 10.1016/S1359-6454(02)000964.

[31] R. Madec, B. Devincre, et L. P. Kubin, «From Dislocation Junctions to Forest Hardening », Phys. Rev. Lett., vol. 89, n 25, p. 255508, déc. 2002, doi: 10.1103/PhysRevLett.89.255508.

[32] G. Sundararajan et Y. Tirupataiah, "The hardness-flow stress correlation in metallic materials ", Bull. Mater. Sci., vol. 17, nº 6, p. 747-770, nov. 1994, doi: 10.1007/BF02757555.

[33] E. M. Lauridsen, H. F. Poulsen, S. F. Nielsen, et D. Juul Jensen, « Recrystallization kinetics of individual bulk grains in 90\% cold-rolled aluminium », Acta Materialia, vol. 51, n 15 , p. 4423-4435, sept. 2003, doi: 10.1016/S1359-6454(03)00278-7.

[34] E. M. Lauridsen, S. Schmidt, S. F. Nielsen, L. Margulies, H. F. Poulsen, et D. J. Jensen, « Nondestructive characterization of recrystallization kinetics using three-dimensional X-ray diffraction microscopy », Scripta Materialia, vol. 55, $\mathrm{n}^{0}$ 1, p. 51-56, juillet 2006, doi: 10.1016/j.scriptamat.2006.02.028.

[35] S. O. Poulsen et al., « In situ measurements of growth rates and grain-averaged activation energies of individual grains during recrystallization of 50\% cold-rolled aluminium », Scripta Materialia, vol. 64, n ${ }^{\circ}$ 11, p. 1003-1006, juin 2011, doi: 10.1016/j.scriptamat.2011.01.046.

[36] A. Khorsand Zak, W. H. Abd. Majid, M. E. Abrishami, et R. Yousefi, « X-ray analysis of ZnO nanoparticles by Williamson-Hall and size-strain plot methods », Solid State Sciences, vol. 13, $\mathrm{n}^{\mathrm{0}}$ 1, p. 251-256, janv. 2011, doi: 10.1016/j.solidstatesciences.2010.11.024.

[37] T. Ungár, J. Gubicza, G. Ribárik, et A. Borbély, «Crystallite size distribution and dislocation structure determined by diffraction profile analysis: principles and practical application to cubic and hexagonal crystals », Journal of applied crystallography, vol. 34, n 3 3, p. 298-310, 2001.

[38] A. Martínez-de-Guerenu, F. Arizti, M. Díaz-Fuentes, et I. Gutiérrez, « Recovery during annealing in a cold rolled low carbon steel. Part I: Kinetics and microstructural characterization ", Acta Materialia, vol. 52, nº 12, p. 3657-3664, juillet 2004, doi: 10.1016/j.actamat.2004.04.019.

[39] M. L. Swanson, "LOW-TEMPERATURE RECOVERY OF DEFORMED ALUMINUM », Canadian Journal of Physics, vol. 42, nº 10, p. 1890-1901, oct. 1964, doi: 10.1139/p64-178.

[40] A. Wauthier-Monnin, "The evolution with strain of the stored energy in different texture components of cold-rolled IF steel revealed by high resolution X-ray diffraction », Materials Characterization, p. 11, 2015.

[41] L.-W. Liang, Y.-J. Wang, Y. Chen, H.-Y. Wang, et L.-H. Dai, « Dislocation nucleation and evolution at the ferrite-cementite interface under cyclic loadings », Acta Materialia, vol. 186, p. 267-277, mars 2020, doi: 10.1016/j.actamat.2019.12.052.

[42] J. Friedel, « Dislocations », p. 517.

[43] G. R. Purdy et Y. J. M. Brechet, « A solute drag treatment of the effects of alloying elements on the rate of the proeutectoid ferrite transformation in steels ", Acta Metallurgica et Materialia, vol. 43, ${ }^{\circ}$ 10, p. 3763-3774, oct. 1995, doi: 10.1016/0956-7151(95)90160-4.

[44] R. B. Sills et W. Cai, "Solute drag on perfect and extended dislocations ", Philosophical Magazine, vol. 96, n 10, p. 895-921, avril 2016, doi: 10.1080/14786435.2016.1142677.

[45] F. Fazeli et M. Militzer, "Application of solute drag theory to model ferrite formation in multiphase steels », Metall and Mat Trans A, vol. 36, n 6, p. 1395-1405, juin 2005, doi: 10.1007/s11661005-0232-y.

[46] B. Zhu et M. Militzer, « Phase-Field Modeling for Intercritical Annealing of a Dual-Phase Steel », Metallurgical and Materials Transactions A, vol. 46, $\mathrm{n}^{\circ}$ 3, p. 1073-1084, mars 2015, doi: 10.1007/s11661014-2698-y. 
[47] A. Béché, H. S. Zurob, et C. R. Hutchinson, « Quantifying the Solute Drag Effect of Cr on Ferrite Growth Using Controlled Decarburization Experiments », Metall and Mat Trans A, vol. 38, $\mathrm{n}^{\circ}$ 12, p. 2950-2955, déc. 2007, doi: 10.1007/s11661-007-9353-9.

[48] R. A. Vandermeer et B. B. Rath, «Interface migration during recrystallization: The role of recovery and stored energy gradients », METALLURGICAL TRANSACTIONS A, p. 7.

[49] H. S. Zurob, C. R. Hutchinson, Y. Brechet, et G. Purdy, « Modeling recrystallization of microalloyed austenite: effect of coupling recovery, precipitation and recrystallization », Acta Materialia, vol. 50, nº 12, p. 3077-3094, juillet 2002, doi: 10.1016/S1359-6454(02)00097-6.

[50] X. Sha et R. E. Cohen, « First-principles thermoelasticity of bcc iron under pressure », Physical Review B, vol. 74, nº 21, p. 214111, décembre 2006, doi: 10.1103/PhysRevB.74.214111.

[51] C. W. Sinclair, C. R. Hutchinson, et Y. Bréchet, "The Effect of Nb on the Recrystallization and Grain Growth of Ultra-High-Purity $\alpha$-Fe: A Combinatorial Approach », Metallurgical and Materials Transactions A, vol. 38, n 4, p. 821-830, juin 2007, doi: 10.1007/s11661-007-9106-9.

[52] H. Zurob, Y. Brechet, et J. Dunlop, «Quantitative criterion for recrystallization nucleation in single-phase alloys: Prediction of critical strains and incubation times », Acta Materialia, vol. 54, $\mathrm{n}^{\circ}$ 15, p. 3983-3990, sept. 2006, doi: 10.1016/j.actamat.2006.04.028. 